\title{
主応力方向に着目した密な砂の非排水 繰返しせん断特性と再圧縮挙動
}

\author{
佐藤研一 ${ }^{1} \cdot$ 安原一哉 ${ }^{2} \cdot$ 吉田信夫 ${ }^{3}$ \\ '正会貝 工修 福岡大学助手 工学部土木工学科（T814-80 福岡市城南区七隈8-19-1） \\ ${ }^{2}$ 正会貝 工博 茨城大学教授 工学部都市システム工学科（テ316 茨城県日立市中成沢町4-12-1) \\ 3正会員 工修 福岡大学教授 工学部土木工学科（T814-80 福岡市城南区七隈8-19-1）
}

\begin{abstract}
中空ねじり試験装置を用いて, 密な砂に対して排水履歴を伴う非排水繰返し試験を行なった. その結果, (1)排水履歴後の過剰間隙水圧とせん断ひずみは, 1 回目の繰返しせん断時における主応力方向, 繰返し応 力比の大きさに影響を受けること, (2)排水履歴後の繰返しせん断举動は主応力方向の変化による構造異 方性に依存すること，(3)排水履歴時に生じる供試体の体積ひずみは，繰返し載荷時に生じた最大せん断 ひずみをパラメータにして整理すると主応力方向, 繰返し応力比の大きさおよび排水履歴の影響を受けな いユニークな関係が存在することが明らかになった。
\end{abstract}

Key Words : undrained cyclic shear, dense sand, liquefaction, repeated load, drainage, recompression

\section{1. まえがき}

著者らは，これまで波による繰返し応力を受ける 海洋構造物下地盤の応力状態を調べるために, FEM を用いた弾性応力解析を行っている ${ }^{1)}$. 解析の結果 から，(1)波浪荷重を受ける海底地盤は，繰返し応力 の主応力方向が場所によって異なっている，(2)その 主応力方向は，波が一方向に作用している間は一定 であり，波が押し波から引き波，あるいは引き波か ら押し波に転じる際にほほ $90^{\circ}$ 反転する特徵を有し ていることを指摘した。そこで, 密な砂供試体を用 い, 非排水繰返しせん断挙動に及ほすす主応力方向の 影響を中空ねじり試験装置を用いて検討を行ってい $ろ^{2), 3)}$. その結果, せん断中の主応力方向の違いによっ て, 非排水繰返しせん断中の過剩間隙水圧およびせ ん断ひずみの挙動が異なることを明らかにした。

一方, 海洋構造物下の地盤は, 図-1に示すように 構造物とこれに作用する波との間の相互作用により， 波浪による外力を繰返し受けている。荒天時には非 常に大きな波浪が防波堤に連続的に繰返し作用する ため, 構造物下の地盤は排水を許すことなく，繰返 し応力が作用する. そのために過剩な間隙水圧が地 盤内に蓄積され，有効応力の低下により緩い砂地盤 では液状化状態になることがある ${ }^{4)}$ 。一方, 波浪が
静穏時に戻った場合は, 砂地盤は透水係数が大きい ために, 発生した過剩間隙水圧が消散し, 地盤は再 圧縮による高密度化が起こる4)。このような地盤の 排水の効果は, 一般に地盤の安定性に対して安全側 に作用すると考えられる。

このように，波浪による繰返し荷重を受ける地盤 は, 有効応力の低下と過剩間隙水圧の消散に伴う圧 縮が常に繰り返される。このような現象を正確に捉 えるためには，(1)波浪による繰返し応力作用後のせ ん断挙動，(2)発生した過剩間隙水圧の消散に伴う圧 縮特性の把握が必須である。前者(1)にについては, 一端液状化した供試体が再圧密によって密度が増加 したにも関わらず，2度目の繰返しせん断に対して 著しく低い抵抗を示す現象に着目した，せん断応力 履歴の影響に関する研究例がある。例えば, Finn et al. ${ }^{5)}$ は, 単純せん断試験装置を用い, 液状化と再液 状化に至るまでの回数比と最初の液状化時の最大履 歴ひずみ振幅の関係を示し，ひずみ振幅が $0.5 \%$ 程度 を越えると, 液状化抵抗が低下することを示した。 一方, Ishihara et al. ${ }^{6) 77}$ は, 飽和砂の繰返しせん断挙 動に及ほす応力履歴の影響を調べるために，静的な 繰返し三軸試験を行って, 排水履歴後のせん断挙動 を考察している，その結果，最初の載荷時に変相線 を越えるような大きな応力履歴を受けると排水履歴 


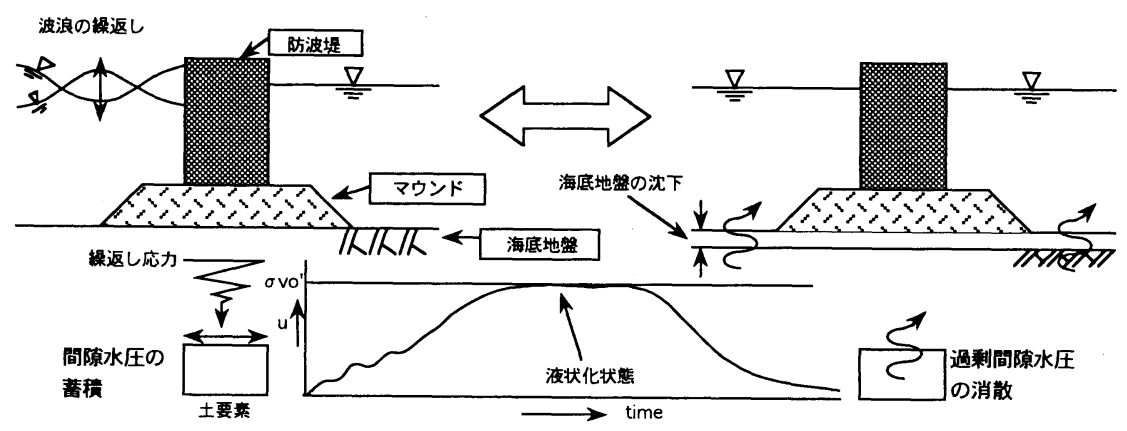

図-1 波浪荷重を受ける地盤の挙動

後の 2 回目の載荷時において, 有効応力の低下が大 きく生じることを示している。また，この有効応力 の低下は, 変相線を越える際の載荷方向に大きく依 存していることも指摘している.

後者(2)については, 特に地震後の地盤沈下に着 目した研究例が数多く見られる. Lee et al. ${ }^{8)}$ は, 繰返 し三軸試験装置を用いて, 液状化後に生じる供試体 の体積ひずみは, 過剩間隙水圧比と一義的な関係が

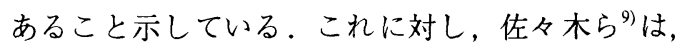

Koリングを用いた繰返しねじり単純せん断試験装置 を用いて液状化による砂地盤の沈下予測法の提案を 行っている.この研究では, 最大せん断ひずみと沈 下指数という載荷後の沈下量と相対密度を乗じた指 数の関係から，沈下予測計算例を示している. 国生 $ら^{100}$ は, 3種類の砂を用い, 相対密度の異なる密な砂 供試体について繰返し三軸試験を行った後に十分な 圧密を行い, 体積圧縮量を測定し, 液状化後の沈下 特性を調べている。その結果, 過剩間隙水圧を消散 させた後の体積ひずみは, 絽返し最大せん断ひずみ, 相対密度, 拘束圧, 細粒分含有率等に依存している という報告をしている。ささらに, Nagase et al. ${ }^{11)} は$, 多方向不規則荷重を受ける砂の沈下特性を二方向単 純せん断装置を用いて調べている。その結果, 載荷 後の排水による体積ひずみは, 最大せん断ひずみと 有意な関係にあることを明らかにしている。 その後, Ishihara et al. ${ }^{12)}$ は, Nagase et al. ${ }^{11)} の$ 示した結果から, 相対密度と最大せん断ひずみをパラメー夕にして求 めた液状化安全率と液状化後の体積ひずみの関係を 用いて, 液状化後沈下計算図表を提案している.

さらに, 社本 ${ }^{13), 14), 15)}$ らは, 余裕間隙比というパラ メ一夕の導入により, 液状化時に発生する両振幅最 大せん断ひずみから，液状化時の沈下量を推定する 手法の提案を行っている.
このように，繰返し載荷を伴う繰返し応力および 排水履歴の現象を把握する研究はこれまでにも数多 く行われているが, 液状化後の地盤の液状化抵抗力 や地盤の沈下量の予測に関しては, 定量的な評価に 未だ不十分なところが残されていると考えられる.

このようなことより, 波による繰返し応力と過剩 間隙水圧の消散に伴う圧縮といった2つの履歴作用 を常に受ける海底地盤の安定性の評価において実験 的な検討は必要不可欠なものである。そこで, 本研 究では, 海底地盤の応力状態に着目し, 構造異方性 を有する密な砂供試体を用いて, 等方圧密終了後, 任意の角度に主軸を固定した非排水繰返しせん断試 験を行った。その後, 発生過剩間隙水圧を消散させ, 再び等方圧密を加え, この過程の実験を1サイクル

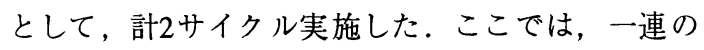
実験結果から排水履歴後の繰返しせん断挙動と繰返 しせん断後の再圧縮挙動に及ほす主応力方向および 繰返し応力の大きさの影響について報告する。

\section{2. 実験概要}

\section{(1) 実験装置}

著者ら ${ }^{1)}$ の研究によると, 波浪荷重の作用する海 洋構造物下の海底地盤の任意の土要素では, 鉛直軸 から一定の傾きを持った繰返し応力が連続的に作用 している．今回実験に使用した試験装置は,このよ うな繰返し応力の作用する状態を再現することの可 能な中空ねじり試験装置である。この試験装置の詳 細は前報2),3)で報告しているのでここでは省略する。 実験に用いた供試体の形状は，外径約 $100 \mathrm{~mm}$, 内径 約 $60 \mathrm{~mm}$, 高さ約 $200 \mathrm{~mm}$ で作成される.メンブレン には, 内・外両方ともに厚さが $0.3 \mathrm{~mm}$ のものを使用 
した。試料には, 豊浦標準砂 $\left(\mathrm{G}_{\mathrm{s}}=2.64, \mathrm{e}_{\mathrm{nax}}=0.991\right.$, $\left.\mathrm{e}_{\mathrm{nn}}=0.623\right)$ を使用して, 供試体の作成と密度の調整 は，空中落下法により行った，供試体作成後，炭酸 ガスと脱気水を供試体に通した後，バックプレッシャー $\sigma_{\mathrm{BP}}=98 \mathrm{kPa}$ 負荷して試料の飽和度を高め, B值が 0.98以上になっていることを確認後, 実験を行った。 また，実験で用いた供試体は相対密度 $80 \%$ とした。

（2）応力とひずみのパラメータ

表-1に，供試体要素に作用する平均的な応力とひ ずみの算定式を示す．今回の応力とひずみの評価法 については, Hight $^{16}$ の提案したものに基づいて行っ ている．表-1に土の状態を表現するために用いたパ ラメー夕を示す。また，今回の全ての計測及び結果 の整理において，別途実施したメンブレン張力の補 正を行っている．さらに，せん断中の供試体の変形 量を供試体内容積の変化量から求めるために，内圧 の変化に伴う内容積測定用ビューレットと供試体内 空部をつなぐ配管の膨張量をあらかじめ検定し，内 容積変化量の補正を行なっている。ただし，メンブ レンの貫入量の補正については，圧密時においては 行っているが, 非排水状態のせん断過程に対しては 行っていない。

\section{（3）実験手順}

今回実施した実験では, 主応力軸を任意の角度に 固定した繰返しせん断試験と繰返しせん断試験後に 排水履歴を供試体に加える実験を行う。そこでまず, 主応力固定型の繰返しせん断試験の方法について述 べる、試験条件は，砂のせん断特性に及ほすと考え られる中間主応力の影響を取り除くために，中間主 応力係数 $\mathrm{b}$ 值を一定に保ち, 主応力方向 $\alpha$ のみを任 意の角度に固定した主応力の反転を伴う両振り試験 である，実験は，応力制御方式のステップ載荷によ り行った。このせん断方法のフローチャートを図-2 に示す。また，図-3に今回実施した試験時の応力経 路を示す。実験ではまず，所定のストレスパスに従 w, 平均主応力 $\mathrm{p}$, 中間主応力係数 $\mathrm{b}$ 值抢よび主応力 方向 $\alpha$ を決定する。これら3つのパラメー夕は，実 験中常に一定とする。本研究では, 平均主応力 $\mathrm{p}=196 \mathrm{kPa}$ ，中間主応力係数 $\mathrm{b}$ 值 $=0.5$ とした. 次に， 1 段階の載荷に必要なせん断応力増分 $\Delta \tau$ を決定し, 必要な鉛直応力 $\sigma_{\mathrm{v}}$, ねじりせん断応力 $\tau_{\mathrm{vh}}$, 内压 $\mathrm{p}_{\mathrm{i}}$, 外圧 $\mathrm{p}_{\mathrm{o}}$ を計算により求め, それぞれ同時に所定の值 まで載荷する，応力状態が所定の応力経路上にある かどうかを確認し，過剩間隙水圧の変化量が $0.98 \mathrm{kPa}$ 以内に落ち着くことを確認してから, 次の載荷ステッ プへ進む。この過程を繰返し，せん断を実施した。
表-1 応力とひずみのパラメータ10

\begin{tabular}{|c|c|c|}
\hline & 庞力 & ひずみ \\
\hline 鉛直方向 & $\sigma_{z}=\frac{W}{\pi\left(r_{o}^{2}-r_{i}^{2}\right)}+\frac{\left(P_{o} \cdot r_{o}^{2}-P_{i} \cdot r_{i}^{2}\right)}{\left(r_{o}^{2}-r_{i}^{2}\right)}$ & $\varepsilon_{z}=\frac{Z}{H}$ \\
\hline 半径方向 & $\sigma_{r}=\frac{P_{o} \cdot r_{o}+P_{o} \cdot r_{i}}{r_{o}+r_{i}}$ & $\varepsilon_{r}=-\frac{u_{o}-u_{i}}{r_{o}-r_{i}}$ \\
\hline 円周方向 & $\begin{array}{c}\sigma_{h}=\frac{P_{o} \cdot r_{o}-P_{o} \cdot r_{i}}{r_{o}-r_{i}} \\
3 \cdot T\end{array}$ & $\begin{aligned} \varepsilon_{h}=- & \frac{u_{o}+u_{i}}{r_{o}+r_{i}} \\
& \Delta \theta \cdot\left(r^{3}-r^{3}\right)\end{aligned}$ \\
\hline 々じりせん断 & $\tau_{v h}=\frac{\pi}{2 \pi \cdot\left(r_{0}^{3}-r_{i}^{3}\right)}$ & $\gamma_{v h}=\frac{\Delta 0 \cdot\left(r_{0}-r_{i}\right)}{3 H \cdot\left(r_{o}^{2}-r_{i}^{2}\right)}$ \\
\hline
\end{tabular}

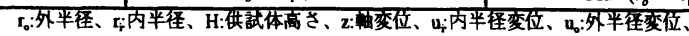
$\Delta \theta:$ ねじ変位

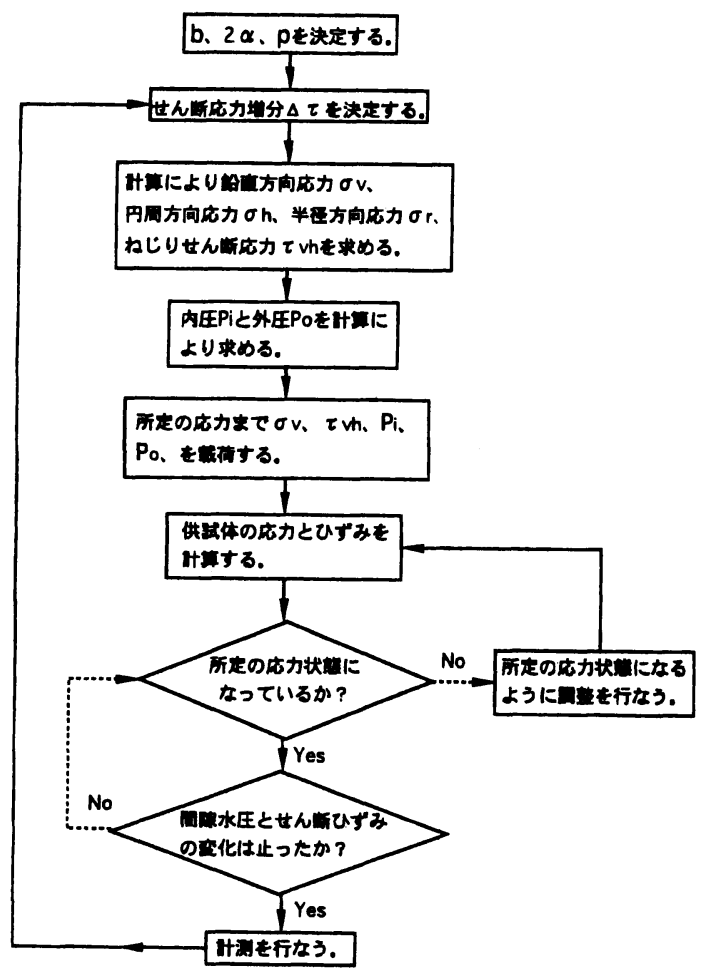

図-2 せん断方法のフローチャート
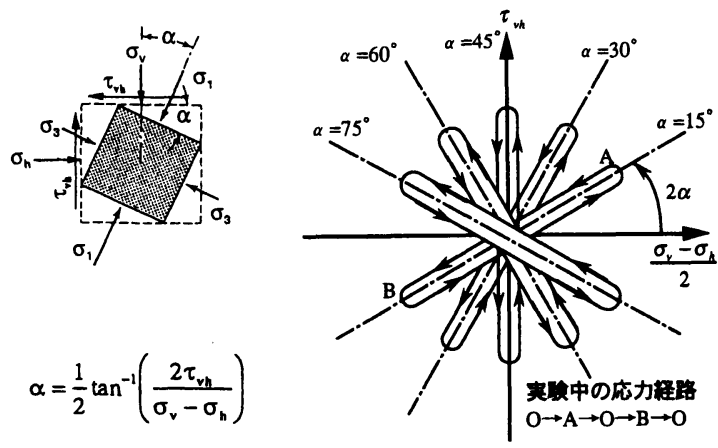

図-3 せん断に用いた応力経路 
次に，実験の模式図を図-4に示す。ここで，(a),(b) (c)はそれぞれ供試体の圧密過程, せん断時の有効応 力経路, 載荷の時刻歴を示している. 実験は, 次の ような手順で行った.

(1)図に示されている点A〜点Bの経路にしたがって， 供試体を压密圧力 $196 \mathrm{kPa}$ で等方圧密させる.

(2)点B～点Cまでせん断条件にしたがって，一定の 繰返し応力比で静的な非排水繰返し荷重を最大5回 加え, 供試体に過剩間隙水圧を発生させる。

(3)繰返し終了後, 発生過剩間隙水圧を消散させる ため排水コックをゆっくりと開け再圧密を行い, 供 試体の体積変化量, 軸変位量を計測する(点C 〜点D).

(4)圧密終了後, 再び(2)と同じ条件で繰返しせん断 試験を行う(点D 点 $\mathrm{E})$.

(5)繰返し終了後, 再び(3)と同様な方法で再々圧密 を行い, 供試体の体積変化量, 軸変位量の計測を行 う (点E 点F).

繰返し応力履歴および排水履歴を調べる実験を実 施する場合, 三軸試験の場合では, 液状化後の供試 体は，伸張側で供試体の中央部がくびれてしまい, 要素性が失われることがある，今回の実験でも，排 水履歴後の供試体の要素性が問題となるが, 供試体 が非常に密な状態であること, 繰返し回数が最大 5 回であることから，排水履歴後も要素性が保たれる と判断した。

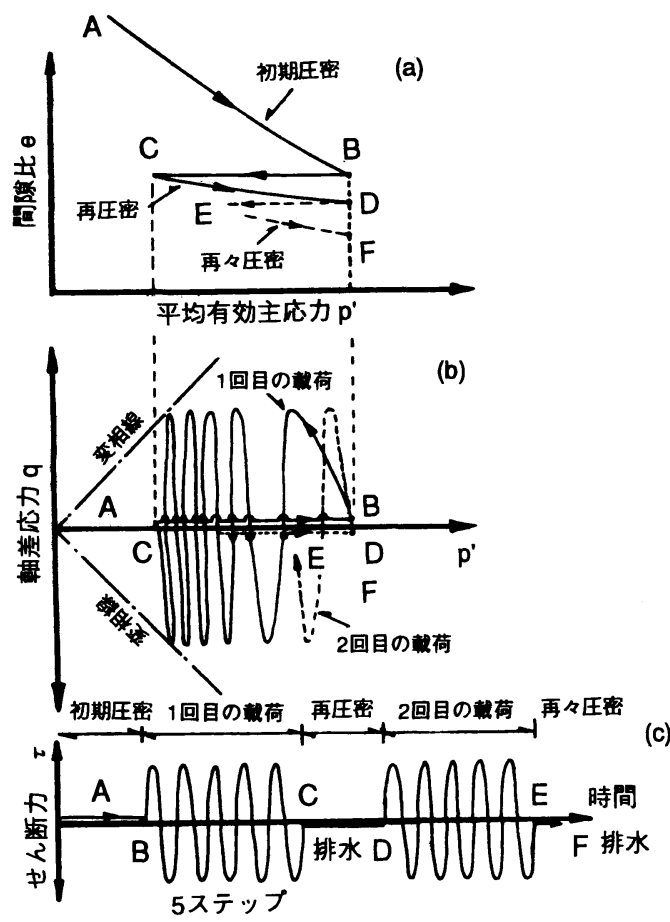

図-4 実験の模式図

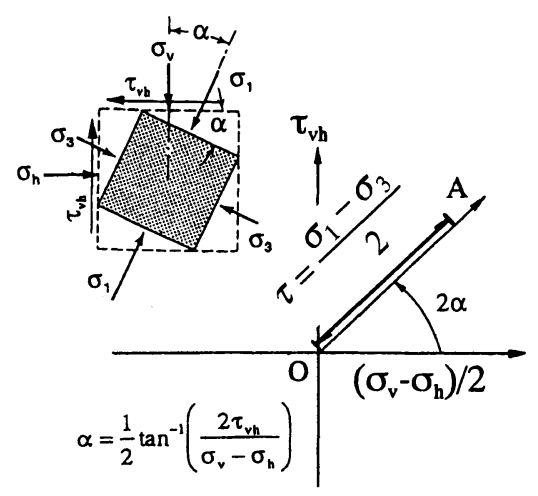

図-5 主応力方向角の定義

表-2 実験に用いた供試体の初期条件

\begin{tabular}{|c|c|c|c|c|}
\hline \multirow{2}{*}{ Test No. } & \multirow{2}{*}{$\begin{array}{c}\text { 主応力方向角 } \\
\alpha\left({ }^{\circ}\right)\end{array}$} & \multirow{2}{*}{$\begin{array}{c}\text { 繰返し応力比 } \\
\tau / \mathbf{p}_{c}{ }^{\prime}\end{array}$} & \multicolumn{2}{|c|}{ 供試体初期間隙比 } \\
\hline & & & 1回目の載荷 & 2回目の載荷 \\
\hline CD151 & 15 & 0.20 & 0.698 & 0.687 \\
\hline CD152 & 15 & 0.24 & 0.695 & 0.682 \\
\hline CD153 & 15 & 0.28 & 0.695 & 0.663 \\
\hline CD301 & 30 & 0.20 & 0.704 & 0.693 \\
\hline $\mathrm{CD} 302$ & 30 & 0.24 & 0.703 & 0.691 \\
\hline $\mathrm{CD} 303$ & 30 & 0.28 & 0.699 & 0.678 \\
\hline $\mathrm{CD} 451$ & 45 & 0.20 & 0.690 & 0.682 \\
\hline $\mathrm{CD} 452$ & 45 & 0.24 & 0.689 & 0.669 \\
\hline $\mathrm{CD} 453$ & 45 & 0.28 & 0.694 & 0.664 \\
\hline CD601 & 60 & 0.20 & 0.690 & 0.673 \\
\hline CD602 & 60 & 0.24 & 0.706 & 0.686 \\
\hline CD603 & 60 & 0.28 & 0.702 & 0.669 \\
\hline CD751 & 75 & 0.20 & 0.696 & 0.679 \\
\hline CD752 & 75 & 0.24 & 0.698 & 0.684 \\
\hline CD753 & 75 & 0.28 & 0.691 & 0.663 \\
\hline
\end{tabular}

実施した繰返し試験では, 繰返し応力比を3 種類 $\left(\tau / \mathrm{p}_{\mathrm{c}}^{\prime}=0.20,0.24,0.28\right)$ に固定して行った. ここで, $\mathrm{p}_{\mathrm{c}}^{\prime}$ は, 圧密終了時の平均有効主応力であり, 今回の実 験では $\mathrm{p}_{\mathrm{c}}^{\prime}=196 \mathrm{kPa}$ である. 用いた繰返し応力比は, 静的な非排水せん断試験における変相時のせん断応 力七の值の約6割前後である。すべての実験におい て主応力方向 $\alpha$ を $15^{\circ}, 30^{\circ}, 45^{\circ}, 60^{\circ}, 75^{\circ}$ の5種類 とした.ここで, 主応力方向とは, 図-5で示した鉛 直軸から最大主応力方向の傾きを $\alpha$ として定義し, 供試体において最初に載荷を加えた方向とする。ま た，繰返し回数は，手動による応力制御のため最大 5回までとした。表-2に実験に用いた供試体の初期 条件をまとめている。 


\section{(1) 主応力方向の違いが排水履歴後のせん断挙動に 及ぼす影響}

図-6，7，8に繰返し応力比が $\tau / p_{\mathrm{c}}^{\prime}=0.24$, 主応力 方向 $\alpha=30^{\circ} ， 45^{\circ} ， 60^{\circ}$ のそれそれの結果を示し ている，また, 各試験結果において, (a) 有効応力経 路, (b) 応力・ひずみ関係, 及び (c) 圧密経路をまと めている.また, 図(a)中に示されいる変相線は, 主 応力方向角の影響を受けることが既往の研究により 報告されている ${ }^{17)}$. そこで, 繰返し試験における最 初の載荷方向と同じ主応力方向の単調載荷試験によ り求められた変相線を記している.

図-6に示している主応力方向 $\alpha=30^{\circ}$ の有効応力 経路は, 1 回目の載荷において繰返し回数 5 サイクル 終了時では变相線に達しておらず, 有効応力の低下 量は約 $50 \%$ 程度である. 排水履歴後の2回目の繰返し 載荷における有効応力の低下量は, 1 回目の繰返し 載荷時の約 3 割程度であり, 過剩間隙水圧の発生量 が抑制されている，応力・ひずみ関係から，排水履 歴後の供試体の変形量は, 1 回目の載荷時に比べ抑 制され，かつ供試体の剛性が上昇している。また， 圧密経路より, 排水履歴による供試体の間隙比の変 化量は, 非排水繰返しせん断による過剩間隙水圧の 消散のために，小さくなっていることが分かる．主 応力方向 $\alpha=30^{\circ}$ の間隙比の変化量は, 1 回目の載荷 による過㮃間隙水圧の量が小さいために, 非常に小 さい. しかし, 過剩間隙水圧の消散に伴う体積変化 によって供試体は高密度化するために，2回目の載 荷に扔いて過㮃間隙水圧の発生量と供試体の変形量 は抑制されたといえる。したがって，排水履歴効果 は, 繰返し載荷後の地盤の高密度化を引き起こし, 地盤の安定化をもたらすと考えられる。

次に, 主応力方向 $\alpha=45^{\circ}$ の結果を図-7に示す. 有効応力経路は, 主応力方向 $\alpha=30^{\circ}$ の結果に比べ, 1回目の繰返し載荷に扔いて有効応力経路は変相線 に達し, サイクリックモビィリティを示している。 また, 有効応力の低下量も全体の約 9 割と非常に大 きい. 排水履歴後に再度同じ条件で繰返し載荷を行 うと，1サイクル目の載荷時において，大きな過剩 間隙水圧の発生とともに有効応力が低下している. その後, すぐに変相線に達した後, 1 回目の載荷に 比べると早い段階で供試体がサイクリックモビィリ ティを示し，液状化状態に至っている，さらに，応 力ひずみ関係からねじりせん断ひずみが1回目の載 荷に比べ, 2 回目の載荷時のひずみ量が大きくなっ ていることも分かる.また, 正の方向(最初にねじり

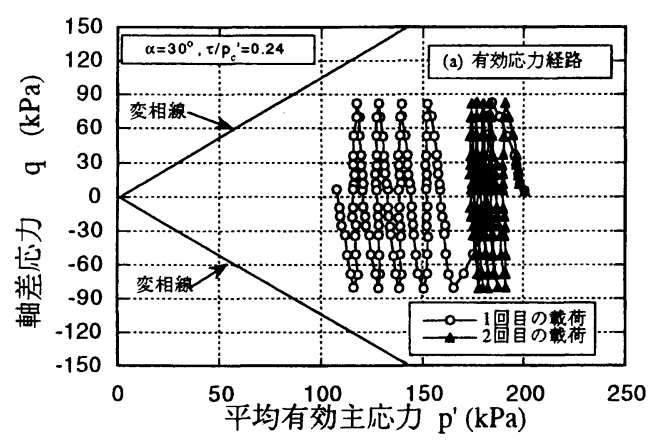

(a)有効応力経路図

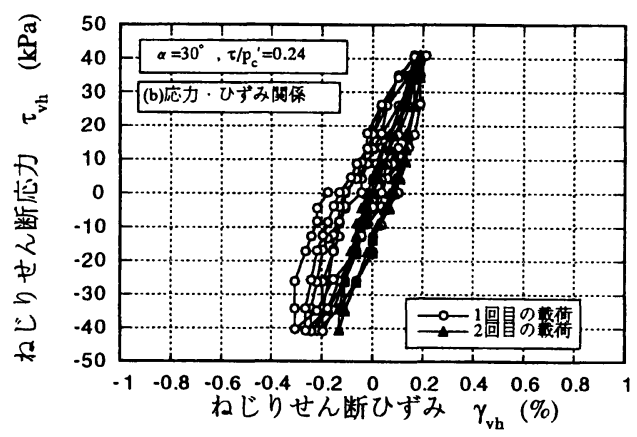

(b)応力・ひずみ経路図

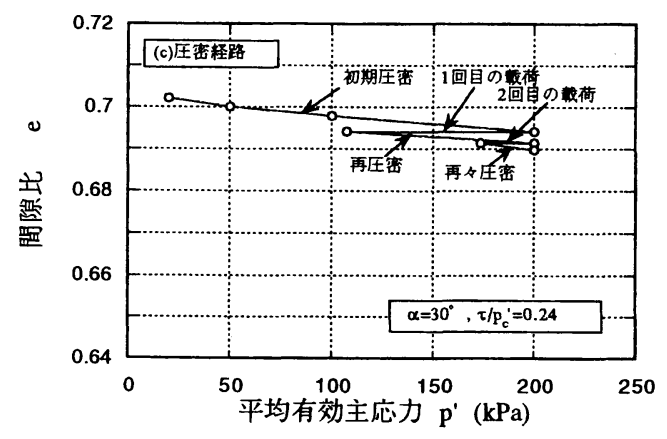

(c)圧密経路図

図-6 排水履歴を伴う繰返しせん断試験結果

(主応力方向角 $\alpha=30^{\circ}$ 、繰返し応力比 $\tau / \mathrm{p}_{\mathrm{c}}{ }^{\prime}=0.24$ )

力を加える方向)のひずみの発生が卓越し，さらに供 試体の剛性が小さくなっていることも分かる．圧密 経路をみると，1回目の載荷で大きな過㮃間隙水圧 を発生しているために, 最初の排水履歴で供試体は, 間隙比で 0.01 程度増加し, 供試体密度がさらに高く なっていることが分かる.これは, 排水履歴後に過 剰間隙水圧が抑制された主応力方向 $\alpha=30^{\circ}$ に比べ るとさらに大きな供試体密度の増加である。しかし, この場合の排水履歴効果は, 履歴後の繰返し載荷の 液状化強度を増加させる効果は見られない。このよ うな再液状化現象は, 液状化により砂の異方性が卓 越するために生じることが, これまでのFinn et al. ${ }^{5)}$, 


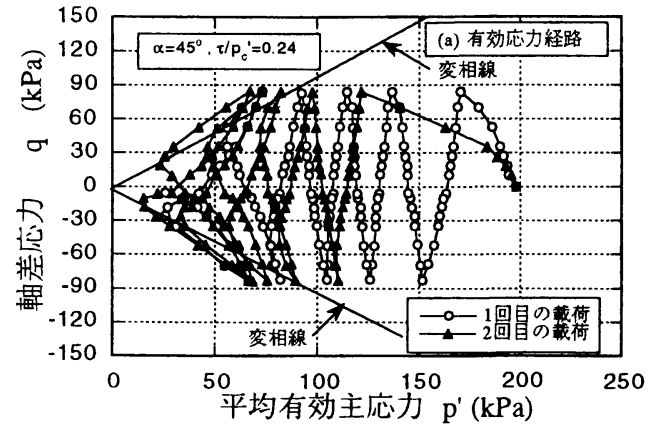

(a)有効応力経路図

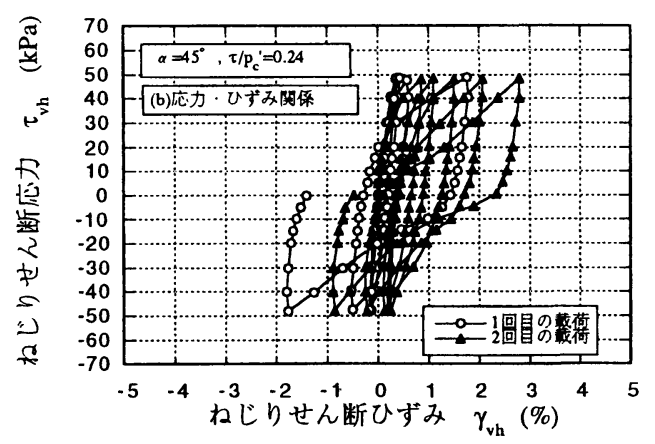

(b)応力・ひずみ経路図

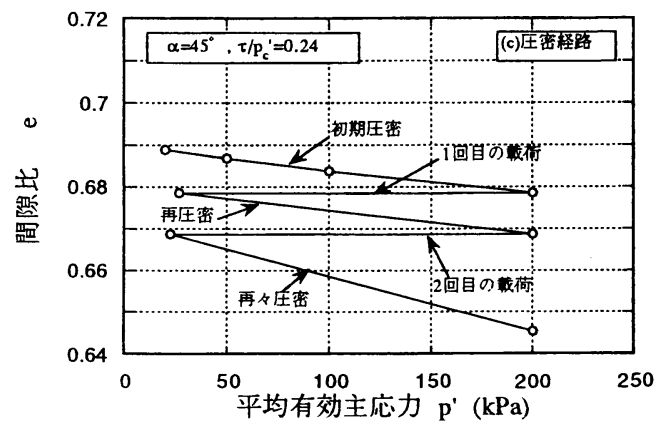

(c)圧密経路図

図-7排水履歴を伴う繰返しせん断試験結果

(主応力方向角 $\alpha=45^{\circ}$ 、繰返し応力比 $\tau / \mathrm{p}_{\mathrm{c}}{ }^{\prime}=0.24$ )

Ishihara et al. ${ }^{6.7)}$, Yoshimi et al. ${ }^{18)}$ らの研究により明か にされてきた。特に, Ishihara et al. ${ }^{6}{ }^{6}$ は, 静的な繰返 し三軸試験を行って, 再液状化過程における有効応 力の低下の過程は, 最初の載荷時において変相線を 越える際の載荷方向に大きく依存していることを示 している，すなわち，2回目の繰返しにおける1サイ クル目の載荷方向が1回目の最後の除荷してきた方 向と反対方向の時に有効応力の低下が大きく生じる と述べている。これは, 最初の載荷によって供試体 の初期構造が破壊され強い異方性を持ったために生 じたものである。今回の実験では, 繰返し載荷中の 中間主応力係数を 0.5 に固定しているため, 繰返し中 にb值が変化する三軸試験とは条件が異なっている。

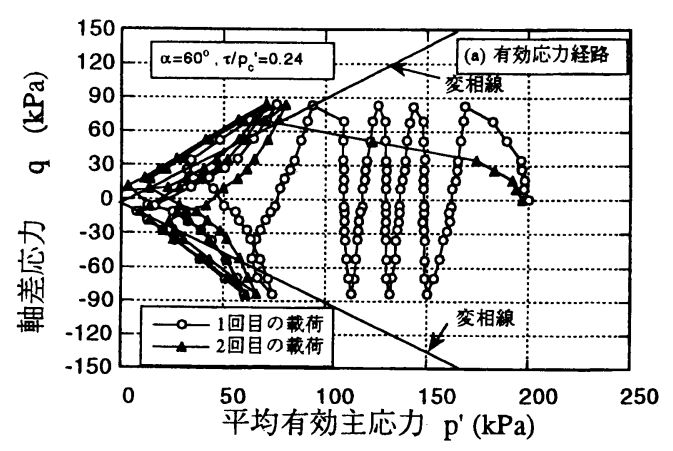

(a)有効応力経路図

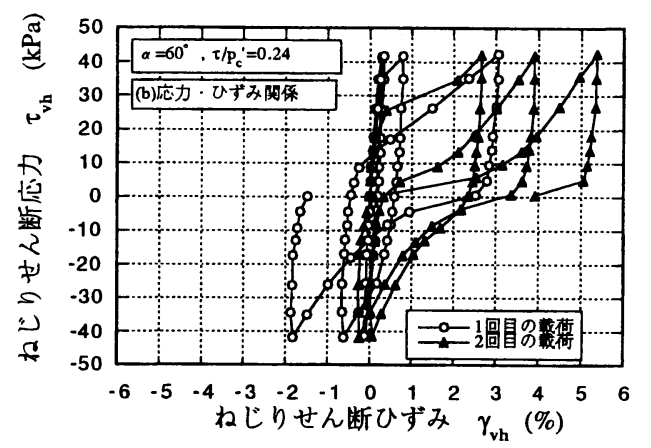

(b)応力・ひずみ経路図

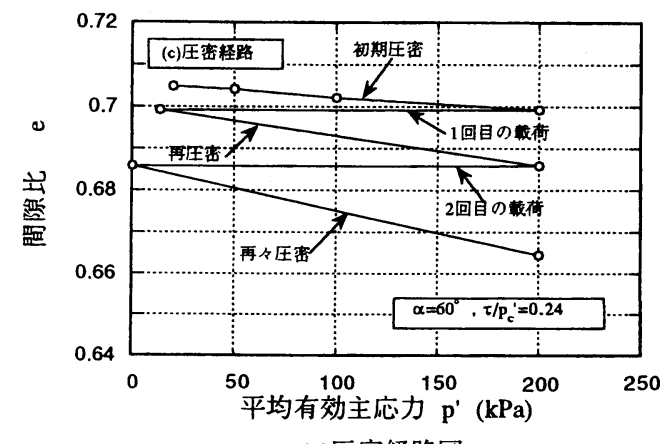

(c)圧密経路図

図-8 排水履歴を伴う繰返しせん断試験結果

(主応力方向角 $\alpha=60^{\circ}$ 、繰返し応力比 $\tau / \mathrm{p}_{\mathrm{c}}^{\prime}=0.24$ )

しかし, 主応力方向が供試体の堆積面から考えると 載荷時と除荷時で $90^{\circ}$ 反転する点では三軸試験と同 じである，したがって，再圧密後の載荷時に大きな 有効応力低下を示したのは, 2 回目の載荷の方向が1 回目の最後の除荷してきた方向と $90^{\circ}$ 反対であるこ とから,この載荷方向の違いから生じる異方性の影 響により強度低下が生じることがより明確になった と言える。

次に, 主応力方向の角度をさらに増加させた $\alpha=$ $60^{\circ}$ の結果を図-8に示している，有効応力経路は, 1 回目の載荷に扔いて繰返し回数4サイクル目の載荷 途中に急に有効応力が低下し，供試体はサイクリッ クモビィリティを示した後, 有効応力は 0 となり, 
液状化状態に至っている。この供試体は, 排水履歴 を加えた後の1サイクル目の載荷において, 有効応 力経路は変相線に達し, 1 回目の載荷時と同様にサ イクリックモビリティを示し, 有効応力はほほ0 と なっている。このような急激な有効応力の低下は, 主応力方向 $\alpha=45^{\circ}$ の結果より顕著である. 応力. ひずみ関係においても，1回目の繰返し載荷による 両振幅ねじりせん断ひずみは, 主応力方向 $\alpha$ の増加 に伴い, 前述した $\alpha=30^{\circ}, 45^{\circ}$ の結果に比べると はるかに大きい。また, 排水履歴後の繰返しせん断 の変形量はさらに大きく, 1 回目の載荷時に比べ, 正の方向(最初にねじり力を加える方向)のひずみの 発生が卓越し，さらに供試体の剛性が大きく低下し ていることも分かる. 排水履歴に伴う間隙比の低下 量についても， $\alpha=30^{\circ}, 45^{\circ}$ の結果に比べると大 きく, 2 回の繰返し載荷と排水履歴によって間隙比 は0.04程度变化し, 供試体は高密度化している。し たがって, 主応力方向 $\alpha=60^{\circ}$.の場合においても, 主応力方向 $\alpha=45^{\circ}$ と同様に排水履歴効果は, 履歴 後の繰返し載荷の液状化強度を増加させる効果はな いことが分かる。

以上, 主応力方向の異なる 3 種類の結果より, 排 水履歴後の繰返しせん断挙動は, 1回目の繰返しせ ん断時の主応力方向の大きさに影響を受けているこ とが明らかになった。また, 繰返しせん断時におけ る載荷時と除荷時の載荷方向の違いによる異方性の 影響により, 排水履歴後に供試体は初期圧密時とは 異なった粒子構造になると考えられる。この粒子構 造の変化は, 繰返し応力を受けた地盤が再圧密され た後, 再び繰返し応力を受け, 再液状化を起こす要 因の1つであるといえる。

次に, 繰返し応力比 $\tau / \mathrm{p}_{\mathrm{c}}^{\prime}=0.24$ の全ての実験結果 について, 各繰返し回数における排水履歴前後の残 留過剩間隙水圧比と主応力方向の関係を図-9にまと めてみた。排水履歴を受けた供試体も 1 回目の載荷 と同様に, 同一繰返し回数の残留過剩間隙水圧が異 なっており, 主応力方向の影響を受けている. 特に, 主応力方向 $\alpha$ が $45^{\circ} \sim 60^{\circ}$ 付近において最も過剩間 隙水圧が生じている。この2つの結果は, 1 回目の載 荷に扔いて有効応力経路が変相線に達し, サイクリッ クモビリティを示した供試体によるものである。一 方, 排水履歴後に有効応力の低下量が抑制されたそ の他の主応力方向においても, 過剩間隙水圧の発生 量の増加過程に若干の主応力方向の影響が見られる。

一方, 各繰返し回数における排水履歴前後の残留 せん断ひずみと主応力方向の関倸をまとめたものが 図-10である。

このことより，排水履歴後の繰返しせん断の残留

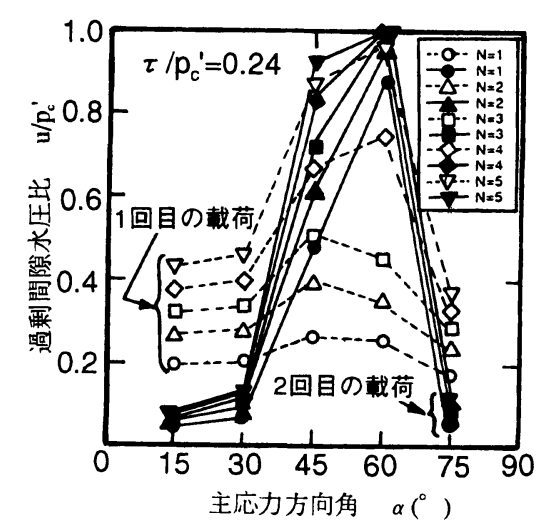

図-9 残留間隙水圧比と主応力方向角の関係

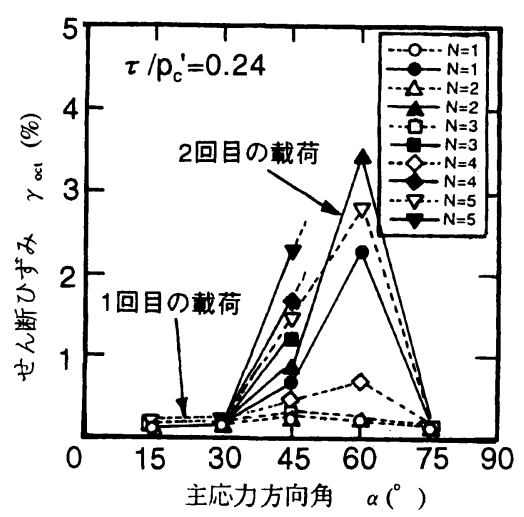

図-10 残留せん断ひずみと主応力方向角の関係

過剩間隙水圧と残留せん断ひずみの発生過程に主応 力方向の違いによる構造異方性の影響が現れること が分かる.

\section{(2) 繰返し応力比の大きさが排水履歴後のせん断挙 動に及ばす影響}

図-11に主応力方向が $\alpha=15^{\circ}$, 繰返し応力比 $\tau$ $/ \mathrm{p}_{\mathrm{c}}{ }^{\prime}=0.20,0.24,0.28$ のそれぞれの有効応力経路を示し ている。最初の載荷において, 有効応力経路が変相 線に達しなかった繰返し応力比 $\tau / \mathrm{p}_{\mathrm{c}}^{\prime}=0.20,0.240$ 結 果では, 2回目の繰返し載荷において, 排水履歴後 により過剩間隙水圧の発生が抑制され，有効応力の 低下が小さくなっている，特に， $\tau / p_{c}^{\prime}=0.24$ の結果 では, 1 回目の過剩間隙水圧の発生量が大きいため, 排水履歴後の有効応力低下量が, 繰返し応力比の小 さい $\tau / \mathrm{p}_{\mathrm{c}}^{\prime}=0.20$ の結果よりも小さくなっていること が特徵的である. 一方, 繰返し応力比 $\tau / \mathrm{p}_{\mathrm{c}}{ }^{\prime}=0.28$ で は, 一回目の載荷において有効応力経路が変相線に 達し, サイクリックモビリティを示して, 液状化状 態に達している. 排水履歴後, この供試体は2回目 

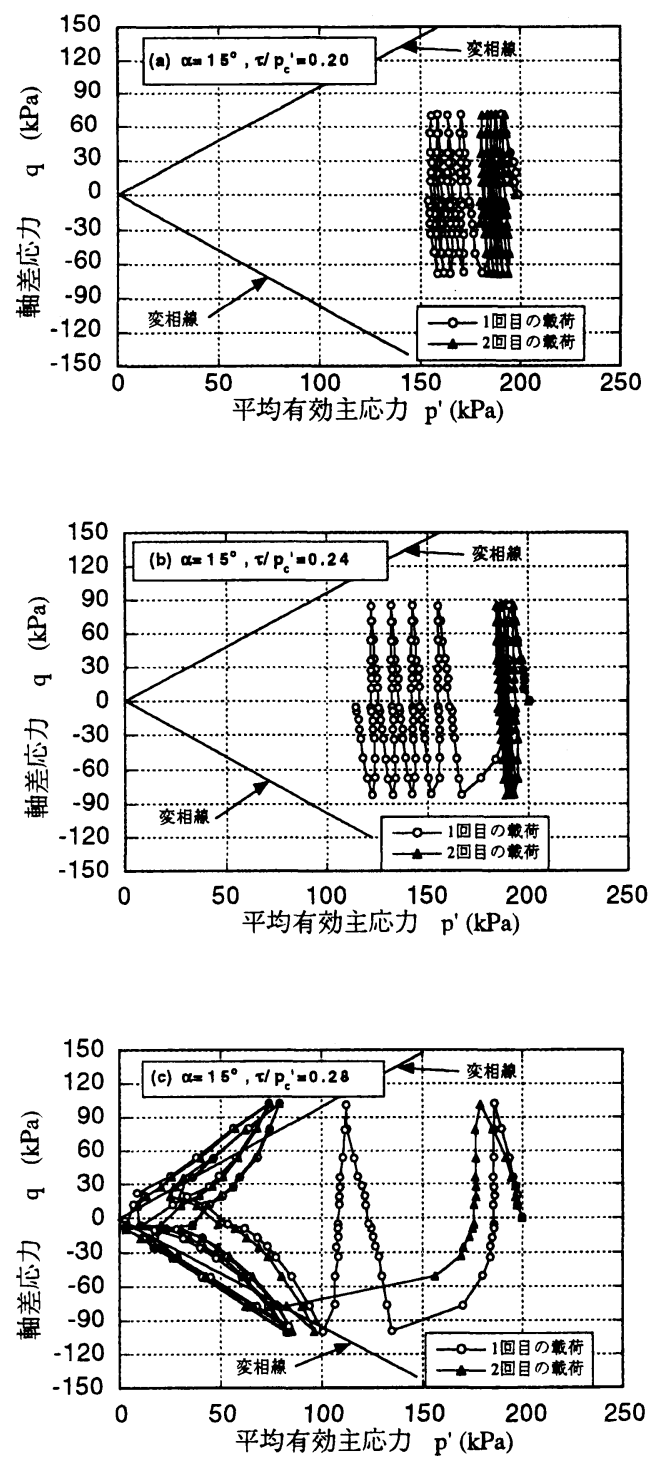

図-11 有効応力経路 $\left(\alpha=15^{\circ}\right)$

の繰返しせん断において，1サイクル目の載荷の途 中に大きな有効応力の低下により変相線に達し, サ イクリックモビリティを示し, 液状化状態に至って いる.

図-12は，主応力方向 $\alpha=30^{\circ}$ についての過剰間隙 水圧比 $\mathrm{u} / \mathrm{p}_{\mathrm{c}}^{\prime}$ と繰返し回数 $\mathrm{N}$ の関係を示したものであ る。排水履歴を受けた後の結果は，排水履歴を受け ていない結果と同様に, 繰返し応力比が $\tau / \mathrm{p}_{\mathrm{c}}^{\prime}=0.20$, $0.24,0.28$ と大きくなるにつれて, 繰返し回数の増 加に伴う正の過剩間隙水圧の蓄積される量も大きく なっていることがわかる。また，1回目の載荷で過 剩間隙水圧比が 0.4 程度しか発生しなかった繰返し応 力比 0.20 と 0.24 ものについては, 排水履歴後にお

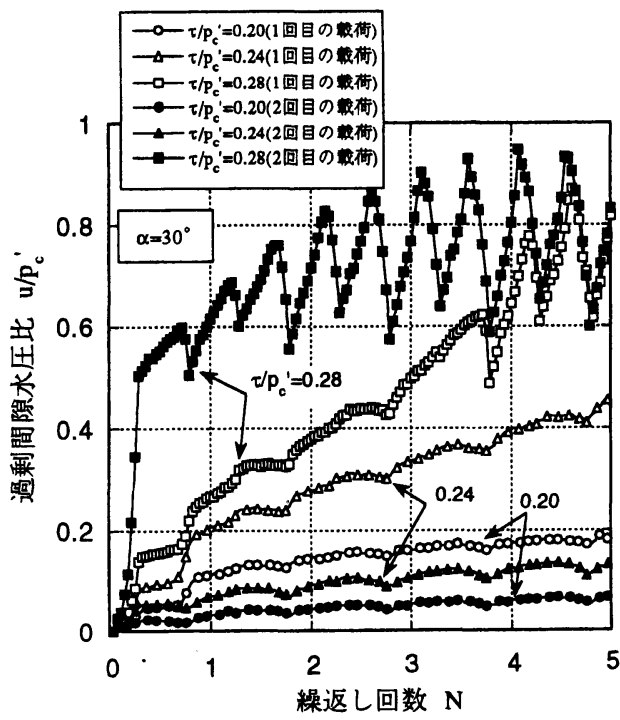

図-12 過㮃間隙水圧比と繰返し回数の関係

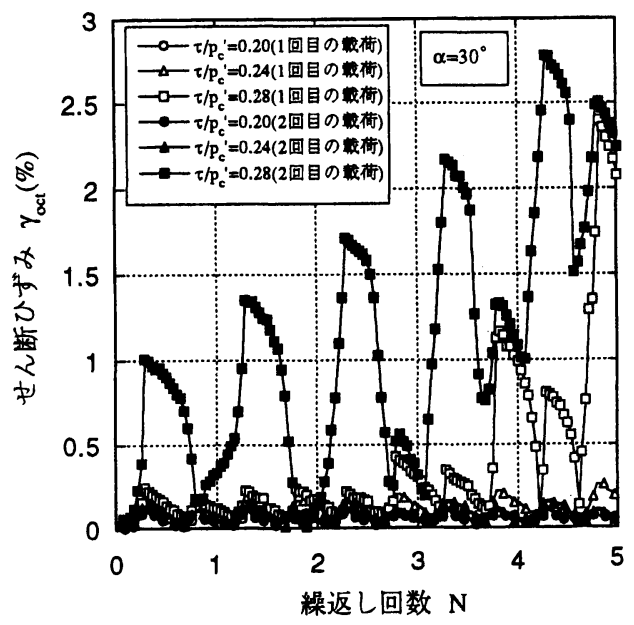

図-13 せん断ひずみと繰返し回数の関係

いて, 過剩間隙水圧の発生量が小さくなっているこ とが分かる。これに対し, 繰返し応力比 0.28 の供試 体については, 1 回目の載荷で過㮃間隙水圧比が 0.6 を超えた付近から過剩間隙水圧が増減を繰返し，大 きな振幅を繰返しながら増加している．排水履歴後 においても, 繰返し回数 1 サイクル目の繰返し載荷 時に急激に過剩間隙水圧が発生し，その後過剩間隙 水圧の増減が起こり, 供試体は液状化に近い状態に 至っていることがわかる.

次に主応力方向が $\alpha=30^{\circ}$ におけるせん断ひずみ $\gamma_{\text {๙ }}$ と繰返し回数Nの関係を図-13に示している.こ の図より, 繰返し回数の増加に伴う残留せん断ひず 
みは, 繰返し応力比が大きくなるにつれて大きくなっ ていることがわかる。また，最初の載荷でせん断ひ ずみがほとんど発生していない繰返し応力比 0.20 と 0.24 の供試体については，せん断ひずみの発生量が 排水履歴による再圧密の効果によって小さくなり, せん断変形挙動が抑制されている。これに対し，最 初の載荷で大きなせん断ひずみが生じ, 塑性変形を 示した繰返し応力比 0.28 の供試体は, 排水履歴後で も繰返し回数1サイクル目の間に急激なせん断ひず みが発生していることが分かる。

図-14は, 1回目の載荷終了時点の発生過剩間隙水 圧比と排水履歴後の同じ時点での発生過剰間隙水圧 比の関係をまとめている。この関係より，1回目の 過剩間隙水圧の発生量が約 0.6 以上に達したものにつ いては，排水履歴後にさらに大きな過剩間隙水圧を 発生させ, 液状化状態になっていることが分かる。

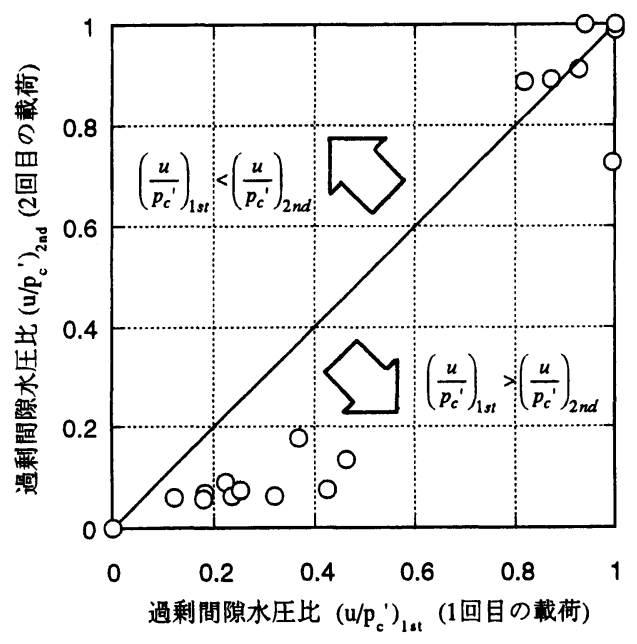

図-14 排水履歴前後の過㮃間隙水圧比の関係

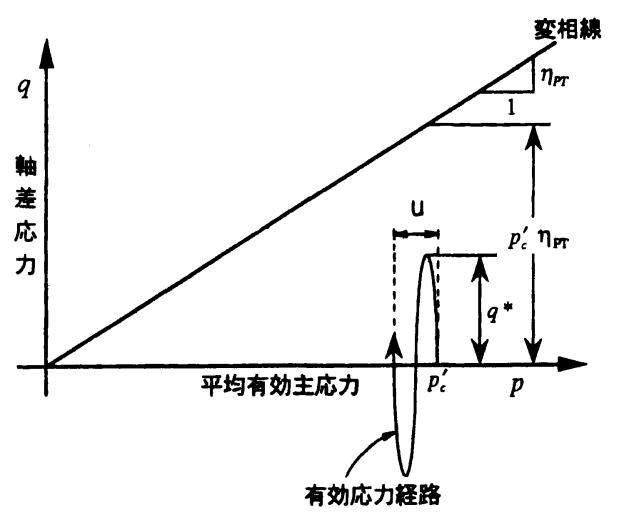

図-15 変相線と有効応力経路の関係
このような挙動を示す供試体の有効応力経路が変 相線に達するまでの過剩間隙水圧は，図-15を参照 すると次式によって与えられる。

$$
\frac{u}{p_{c}{ }^{\prime}}=1-\left(\frac{q^{*}}{p_{c}{ }^{\prime}}\right) \cdot \frac{1}{\eta_{P T}}
$$

ここで, $\mathrm{u}$ は, 発生過剩間隙水圧, $\mathrm{p}_{\mathrm{c}}^{\prime}$ 'は, 压密時の 平均有効主応力, $\eta_{\mathrm{Pr}}$ は, 変相線の傾き, $\mathrm{q}^{*}$ は, 片 振幅の軸差応力である。

計算の結果, 変相線の傾き, 繰返し応力の大きさ が各実験条件によって異なるが，今回の実験の範囲 では平均的に初期の平均有効主応力 $\mathrm{p}_{\mathrm{c}}$ から約 6 割程 度の低下によって, 有効応力経路がいずれの場合も 変相線に達することが明らかになった，言い換えれ ば，1回目の載荷によって変相線に達するような繰 返しせん断履歴を受けた供試体は2回目の繰返し載 荷によって再液状化を起こすことを示唆している。

\section{(3)排水履歴後の再圧縮挙動}

図-16に，各繰返し応力比において1回目の繰返し 載荷終了時に発生した過剩間隙水圧比 $\mathrm{u} / \mathrm{p}_{\mathrm{c}}^{\prime}$ と主応力 方向 $\alpha$ の関係と併せて過剩間隙水圧の消散に伴って 生じた体積ひずみ $\varepsilon_{\text {vd }}$ との関係を示している。 また, 2回目の繰返し載荷終了時における結果も図-17に示 している。これらの結果より, 繰返し載荷終了時の 過剰間隙水圧の発生量は, 主応力方向の変化に伴っ て異なっていることが分かる．特に, 繰返し応力比 $\tau / \mathrm{p}_{\mathrm{c}}{ }^{\prime}=0.24$ の結果では, 1 回目の載荷および2回目の 載荷ともに主応力方向 $\alpha=45^{\circ} \sim 60^{\circ}$ において最も 大きな過剩間隙水圧を示している。一方，供試体の 体積ひずみは, 過剩間隙水圧が大きくなるにともなっ て増加しており, 繰返し応力比, 繰返し載荷中の主 応力方向に関係なく，両者の関係は一義的に決まる といえる。そこで, 再圧密時と再々圧密時における 体積ひずみと過剩間隙水圧比の関係をまとめたもの が図-18である．図中には多方向不規則せん断を実 施したNagase $ら^{11)}$ のr=73\%の結果も併記している。 今回の実験結果では, Nagaseら ${ }^{11)}$ の実験で用いられ た供試体密度とは若干異なるが, $\varepsilon_{\mathrm{vd}} \sim u / p_{c}^{\prime}$ の関係は 1回目および2回目の載荷ともにNagase ら ${ }^{11)}$ の結果と 同様な傾向を示している。 また，1回目の載荷時に 比べると2回目の載荷時の方が体積ひずみが小さく なる傾向も見られる。これは，供試体密度の増加に よる影響と考えられ, Nagaseら ${ }^{11}$ も同様な傾向があ ることを指摘している。しかし，図-18において過 剩間隙水圧比 $\mathrm{u} / \mathrm{p}_{\mathrm{c}}$ 'が1.0付近(すなわち，供試体が液状 


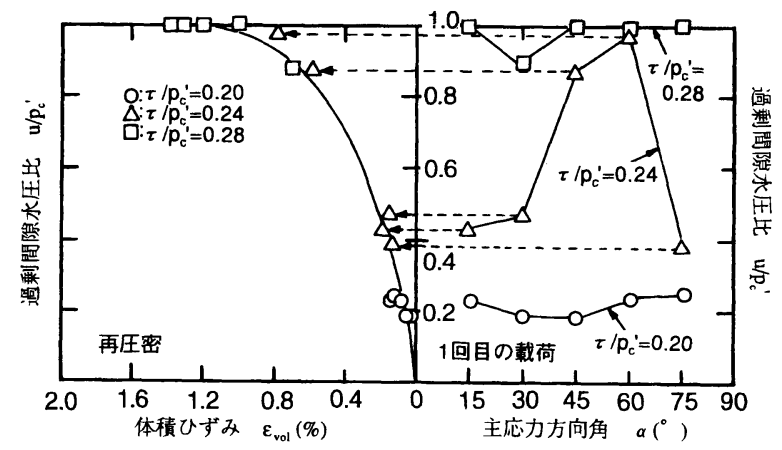

図-16 主応力方向角と過剰間隙水圧および体積ひずみの関係

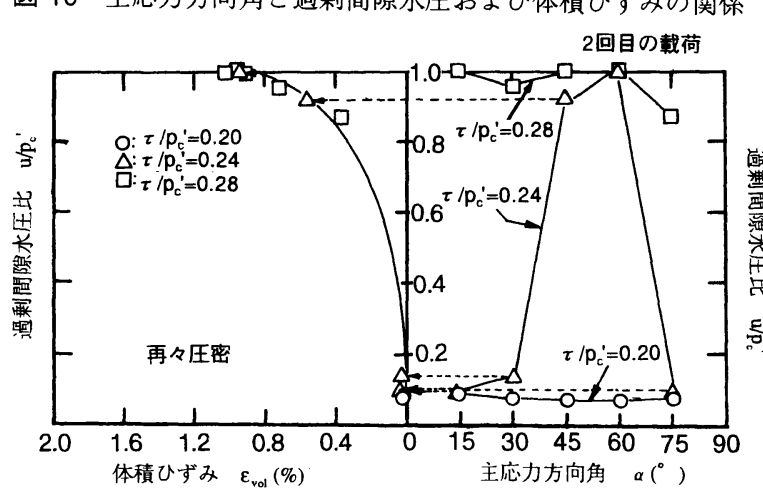

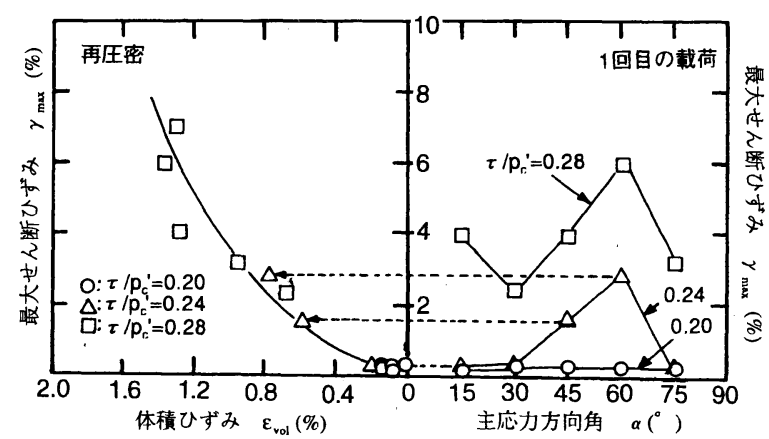

図-19 主応力方向角と最大せん断ひずみおよび体積ひずみの関係

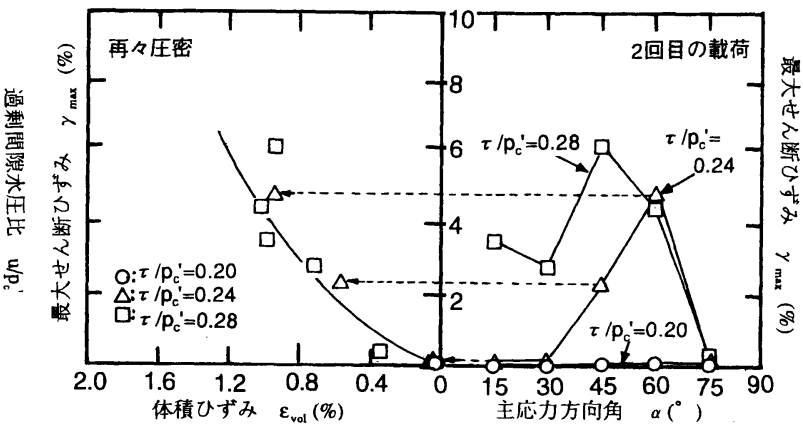

図-17 主応力方向角と過剰間隙水圧および体積ひずみの関係 図-20 主応力方向角と最大せん断ひずみおよび体積ひずみの関係

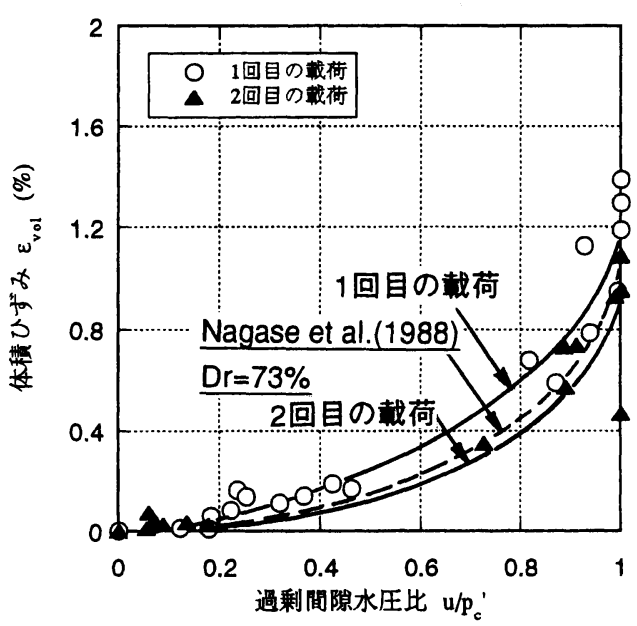

図-18 体積ひずみと過鄱間隙水圧の関係

化に近い状態にある場合)では，体積ひずみにばらつ きが見られ，液状化後の地盤沈下を発生過剩間隙水 圧から予測することは困難であることが示唆される。 一方，1回目の繰返し載荷終了時に発生した最大せ ん断ひずみ $\gamma_{\text {max }}$ 及び主応力方向 $\alpha$ と体積ひずみ $\varepsilon_{\mathrm{vol}}$ との関係は図-19に示す通りである。また，図 -20は，2回目の繰返し載荷終了時の結果である.1 回目および2回目に生じた繰返し載荷時ともに，最
大せん断ひずみ $\gamma_{\text {max }}$ は主応力方向 $\alpha$ の影響を受けて いる。また，1回目および2回目の最大せん断ひずみ は, 繰返し応力比の増加に伴って大きくなっている. 一方, 繰返し応力比, 主応力方向の大きさに関係な く，最大せん断ひずみの増加に伴い体積ひずみが増 加する傾向があり，両者にはユニ一クな関係がある ことも分かる.

そこで，体積ひずみ $\varepsilon_{\text {vol }}$ と繰返しせん断時の最大 せん断ひずみ $\gamma_{\operatorname{mxx}}$ の関係をまとめてみた。その結果, 図-21に示すように若干のデータのばらつきはある が再圧密時と再々圧密時ともに，最大せん断ひずみ と体積ひずみの関係が以下に示す一つの式

$$
\varepsilon_{v o l}=0.37 \gamma_{\max }^{0.72}
$$

で近似することが可能であることが分かる。

この関係により，繰返しせん断履歴後の体積ひず みは, 繰返しせん断試験中の主応力方向の違いによ る供試体の初期構造異方性, 繰返し応力の大きさ, 排水履歴によらず， $\gamma_{\max }$ のみの関数として近似的に 予測することが可能である。このように, 砂の繰返 しせん断履歴後の体積変化量は, 従来加指摘され 


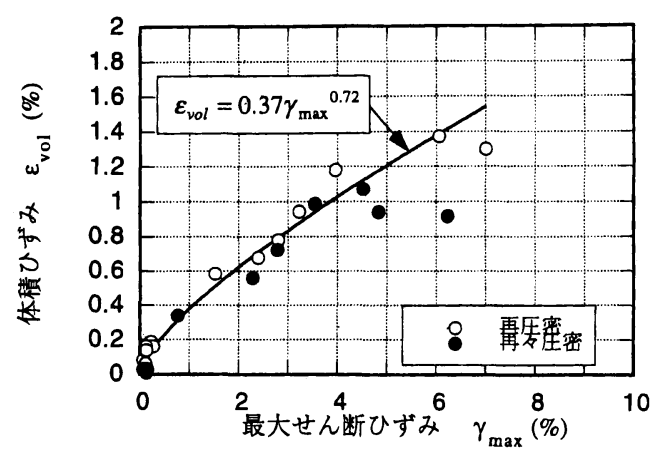

図-21 体積ひずみと最大せん断ひずみの関係

ているように, 過剩間隙水圧ではなく, 最大せん断 ひずみをパラメ一タを用いることにより, 繰返し応 力の大きさや供試体の初期構造異方性の影響揖よび 排水履歴による供試体の構造変化を考慮せずに予測 することが可能であることが示唆される。

\section{4. 結論}

主応力方向の違いに着目した排水履歴を伴う密な 砂の非排水繰返しせん断試験を行った結果から, 次 のようなことが明かになった。

(1)過剩間隙水圧およびせん断ひずみに大きな影響を 与える要因である繰返しせん断時の主応力方向と繰 返し応力比の大きさは, 排水履歴後のせん断挙動を 左右する。

(2)繰返し荷重を受けた地盤の排水履歴効果は, 地盤 を安定させる場合とそうでない場合がある，特に， 排水履歴時の密度増加にも関わらず，排水履歴後の 繰返しせん断時に強度低下を示すのは, 2回目の載 荷方向が1回目の最後の除荷してきた方向と $90^{\circ}$ 反 対方向であるために生じる載荷方向の違いによる異 方性の影響である。

(3)2回目の繰返しせん断時における過剩間隙水圧お よびせん断ひずみの発生過程においても, 主応力方 向の違いによる構造異方性の影響が存在する.

(4)繰返しせん断によって発生する過剩間隙水圧は, 主応力方向と繰返し応力比の大きさの影響を受ける。 しかし, 排水履歴によって生じる体積ひずみと過剩 間隙水圧比の関係は, 過剩間隙水圧比が 1.0 付近の液 状化に近い状態を除いて一義的な関係がある.

(5)体積ひずみを最大せん断ひずみをパラメータにし て整理すると両者は, 主応力方向の変化による初期 構造異方性の影響や繰返し応力の大きさおよび排水 履歴による供試体の構造変化によらないユニークな
関係が存在する。

謝辞：本研究における実験, デー夕整理等で協力し てくれた，高木操君（東急建設(株)），平岡呂晃君 （神戸市）に心から感謝の意を表します。

付録：記号説明

$$
\begin{gathered}
\tau_{\mathrm{vh}}: \text { ねじりせん断応力 }(\mathrm{kPa}) \\
\tau: \text { せん断応力 }(\mathrm{kPa})
\end{gathered}
$$

$$
\tau=\frac{\sigma_{1}-\sigma_{3}}{2}
$$

$\mathrm{u}:$ 過剩間隙水圧 $(\mathrm{kPa})$

$\alpha:$ 主応力方向(deg.)

$\gamma_{\mathrm{vh}}$ : ねじりせん断ひずみ $(\%)$

$\gamma_{\text {occ }}:$ せん断ひずみ(\%)

$$
\gamma_{o c t}=\frac{2}{3} \sqrt{\left(\varepsilon_{1}-\varepsilon_{2}\right)^{2}+\left(\varepsilon_{2}-\varepsilon_{3}\right)^{2}+\left(\varepsilon_{3}-\varepsilon_{1}\right)^{2}}
$$

$\gamma_{\text {max }}$ : 最大せん断ひずみ(\%)

$\mathrm{p}$ : 平均主応力 $(\mathrm{kPa})$

$\mathrm{p}_{\mathrm{c}}$ : 圧密終了時の平均有効主応力 $(\mathrm{kPa})$

b: 中間主応力係数

$\mathrm{q}$ : 軸差応力 $(\mathrm{kPa})$

$q=\sqrt{\frac{1}{2}\left(\sigma_{1}-\sigma_{2}\right)^{2}+\left(\sigma_{2}-\sigma_{3}\right)^{2}+\left(\sigma_{3}-\sigma_{1}\right)^{2}}$

$\mathrm{q}^{*}$ : 繰返し軸差応力 $(\mathrm{kPa})$

$\varepsilon_{\mathrm{vol}}:$ 体積ひずみ $(\%)$

$\mathrm{N}$ : 繰返し回数

\section{参考文献}

1) 佐藤研一, 高木操, 安原一哉, 見郷浩二: 波浪荷重を受 ける防波堤下砂地盤の挙動に関する研究, 茨城大学工 学研究集報, Vol.41, pp.1-15, 1993.

2) 佐藤研一, 吉田信夫, 安原一哉, 高木操:波浪荷重を受 ける防波堤下地盤の繰返しせん断挙動, 第39回土質工 学シンポジュウム論文集-海底地盤と海洋施工技術-, pp.211-218, 1994.

3) 佐藤研一, 安原一哉, 桶口徹, 吉田信夫: 密な砂の非排 水繰返しせん断挙動に及ほす寸主応力方向の影響, 土木 学会論文集,No.541/III-35,pp.199-213,1996.

4 ) 善功企: 海底地盤の波浪による液状化に関する研究, 九州大学学位請求論文, 1992.

5) Finn,W.D.L., P.L. Bransby and D.J.Pickering : Effect of 
strain history on liquefaction of sand, J.SMFD, ASCE, Vol.96, No.SM6,PP.1917-1934,1970.

6) Ishihara,K. and Okada,S.:Effect of stress history on cyclic behavior of sand, Soils and Foundations, Vol.18, No.4, pp.31-45, 1978.

7) Ishihara,K. and Okada,S. : Effect of large pre-shearing on cyclic behavior of sand, Soils and Foundations, Vol.22, No.3, pp.109-125, 1982.

8) Lee,K.L. and A. Albaisa : Earthquake induced settlements in saturated sands, J.GED, ASCE, Vol.100, No.GT.4, pp. 81-92,1974.

9）佐々木勉, 龍岡文夫, 山田真一: 液状化による砂地盤の 沈下予測について, 第17回土質工学研究発表会講演概 要集,pp.1661-1664,1982.

10) 国生剛治, 長崎 清: 密な砂地盤の液状化後の沈下特 性, 第19回土質工学研究発表会講演概要集 , pp.563566,1984 .

11) Nagase,H. and Ishihara, K. : Liquefaction-induced compaction and settlement of sand during earthquakes, Soils and Foundations, Vol.28,No.1,pp.83-94,1988.

12) Ishihara, K. and Yoshimine, M. : Evaluation of settlements in sand deposits following liquefaction during earthquakes, Soils and Foundations, Vol.32, No.1, pp.
$173-188,1992$

13) 社本康広, 佐藤正義: 液状化時の地盤沈下量の予测, 繰返し応力を受ける地盤の変形に関するシンポジュウ 么発表論文集, pp.15-18, 1990.

14) 社本康広, 佐藤正義: 液状化時の沈下量の推定法, 第26回土質工学研究発表会講演概要集, pp.765-766, 1991.

15) Shamoto, Y., Sato, M. and Zhang, J.: Simplified estimation of earthquake-induced settlements in saturated sand deposits, Soils and Foundations, Vol.36, No.1, pp. 39-50, 1988.

16) Hight, D.W. : Laboratory investigations of seabed clays, $\mathrm{Ph}$. D Thesis submitted to the University of London, 1983.

17) Yasufuku, N., Nakata, Y. and Murata, H. : Flow deformation of sand under $\sigma_{1}$-axis rotaion, 10th Asian Regional conf. on SMFE, pp.115-118,1995.

18) Yoshimi,Y., F.Kuwabara and K.Tokimatsu : One-dimensional volume change characteristics of sands under very low confining stresses, Soils and Foundations, Vol.15, No.3, pp.51-60, 1992.

(1996.4.10 受付)

\title{
EFFECT OF PRINCIPAL STRESS DIRECTION ON UNDRAINED CYCLIC SHEAR AND RECOMPRESSION BEHAVIOUR OF DENSE SAND
}

\author{
Ken-ichi SATO, Kazuya YASUHARA and Nobuo YOSHIDA
}

\begin{abstract}
A series of cyclic torsional shear tests has been carried out to investigate the effect of drainage with preshearing on behavior of dense sand. The results of experiment indicate:(1) the magnitude of excess pore pressure and shear strain after drainage history is influenced by both the principal stress direction and the magunitude of cyclic stress ratio at cyclic loading, (2) the variations of excess pore pressure and shear strain with number load cycles after drainage history depends on principal stress direction, (3)recompression volumetric strain due to dissipation of cyclic-induced excess pore pressure can be related to the maximum shear strain observed during cyclic shear, irrespective of the angle of principal stress direction, cyclic stress ratio and drainage history.
\end{abstract}

